\title{
Dermatological sequela of a car accident: acquired Port-wine stain (Fegeler syndrome)
}

\author{
Yvonne Nussbaumer-Ochsner, ${ }^{1}$ Giatgen Spinas ${ }^{2}$
}

${ }^{1}$ Division of Pulmonology, University Hospital of Zürich, Zürich, Switzerland

${ }^{2}$ Division of Endocrinology, University Hospital of Zurich, Zürich, Switzerland

\section{Correspondence to} Dr Yvonne NussbaumerOchsner,

yvonne.nussbaumer@hispeed.ch

Accepted 12 July 2015
CrossMark

\begin{tabular}{l}
\hline To cite: Nussbaumer- \\
Ochsner Y, Spinas G. BMJ \\
Case Rep Published online: \\
[please include Day Month \\
Year] doi:10.1136/bcr-2015- \\
210860
\end{tabular}

\section{DESCRIPTION}

A 71-year-old man with long-standing type 2 diabetes mellitus was admitted for optimisation of glucose control. His antihyperglycemic medication comprised metformin, glimepiride and insulin glargine at bedtime. He also reported mildly impaired cognitive function and short-term memory. On physical examination, numerous well-defined erythematous spots, telangiectasis and striae distensae, spread over the abdomen, were detected (figures 1 and 2). Differential diagnosis included skin changes due to a glucagonoma, hypercortisolism or another acquired vascular lesion of the skin. Laboratory evaluation yielded glycated haemoglobin (HbA1c) of $8.6 \%$, a physiological dexamethasone suppression test and a normal urinary cortisol excretion; plasma glucagon concentration was within the reference range.

Thorough medical history taking revealed a car accident 4 years earlier and that the skin changes appeared thereafter. Skin biopsy showed ectatic dilated capillaries in the superficial dermis (figure 3) and in the context of the car accident a diagnosis of

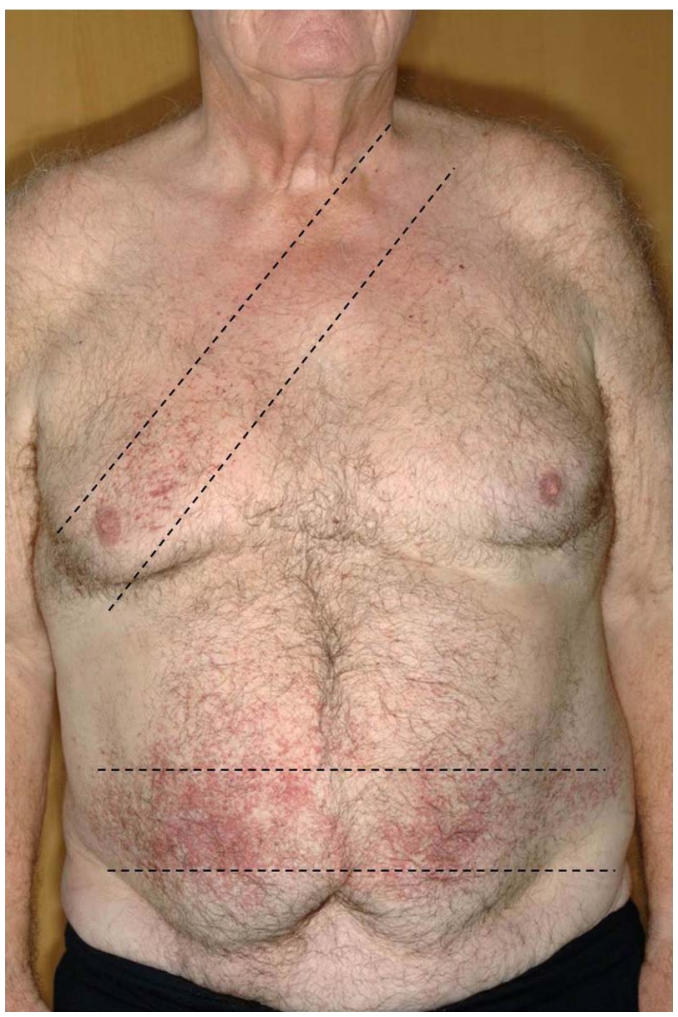

Figure 1 Skin changes over the abdomen clearly constrained to the surface of the seat belt (dotted lines).

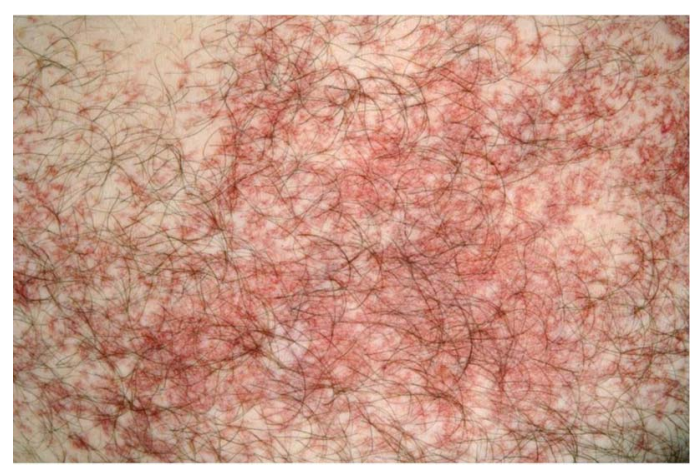

Figure 2 Higher magnification of figure 1 showing numerous well-defined erythematous spots and telangiectasis.

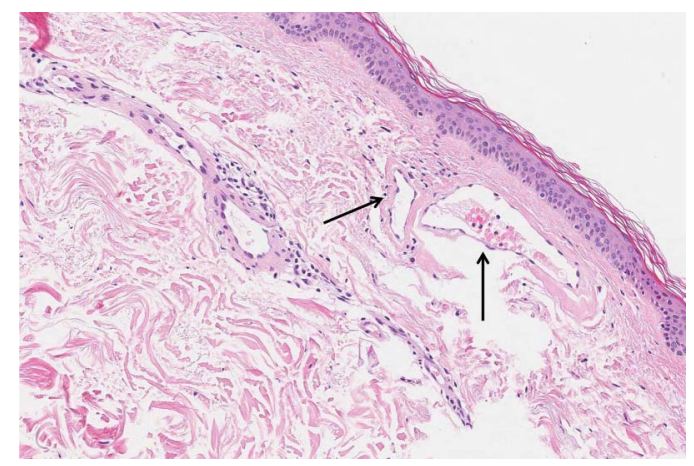

Figure 3 Skin biopsy showing dilated and ectatic capillaries of the superficial dermis (arrow). Original magnification: $\times 20$.

acquired Port-wine stain (PWS) (nevus flammeus, Fegeler syndrome) was made.

PWS are vascular malformations with normal endothelial cell cycles and are most often congenital. Acquired forms of PWS are morphologically indistinguishable from congenital PWS. ${ }^{1}$ It is suggested that the histopathological features consisting of dilated, ectatic capillaries arise from malformed sympathetic innervation. A preceding trauma is among the most frequent causes of acquired PWS. ${ }^{1-3}$ Pathogenetically, it is assumed that traumatic injury of the skin induces perivascular atrophy leading to vessel dilation or that impaired reparative processes in vessels result in dilated vessel walls. Cases of non-trauma-related PWS have been described in conjunction with the intake of isotretinon, ${ }^{4}$ oral contraceptives, simvastatin and metformin. 


\section{Learning points}

- Port-wine stains (PWS) are vascular malformations usually present at birth. Acquired PWS are infrequently reported in the literature and have mostly been attributed to mechanical trauma. Trauma-related PWS are also called Fegeler syndrome, named so after Fegeler, who first described a case of a trauma-related PWS.

- Dermatological examination reveals well-defined erythematous macules. Histologically, these changes refer to dilated, ectatic vessels.

- Laser (especially pulsed dye laser) is the treatment of choice. Acquired PWS tend to better respond to treatment than congenital PWS.

Acknowledgements The authors would like to thank PD Katrin Kerl French, Division of Dermatology, University Hospital Zurich, for performing the histological analysis.
Contributors $\mathrm{YN}-\mathrm{O}$ was responsible for collecting the patient data/material and writing the manuscript. GS was responsible for revising the manuscript.

Competing interests None declared.

Patient consent Obtained.

Provenance and peer review Not commissioned; externally peer reviewed.

\section{REFERENCES}

1 Adams BB, Lucky AW. Acquired Port-wine stains and antecedent trauma: case report and review of the literature. Arch Dermatol 2000;136:897-9.

2 Piaserico S, Belloni Fortina A. Posttraumatic Port-wine stain in a 4-year-old girl: Fegeler syndrome. Pediatr Dermatol 2004;21:131-3.

3 Bansal S, Garg VK, Wadhwa B, et al. Acquired Port-wine stain in an adult male: first reported case from India with review of the literature. Indian I Dermatol 2015;60:104.

4 Hoque S, Hoden C. Acquired Port wine stain following oral isotretinoin. Clin Exp Dermatol 2005;30:587-8.

Copyright 2015 BMJ Publishing Group. All rights reserved. For permission to reuse any of this content visit http://group.bmj.com/group/rights-licensing/permissions.

BMJ Case Report Fellows may re-use this article for personal use and teaching without any further permission.

Become a Fellow of BMJ Case Reports today and you can:

- Submit as many cases as you like

- Enjoy fast sympathetic peer review and rapid publication of accepted articles

- Access all the published articles

- Re-use any of the published material for personal use and teaching without further permission

For information on Institutional Fellowships contact consortiasales@bmjgroup.com

Visit casereports.bmj.com for more articles like this and to become a Fellow 